\title{
The contribution of natural and anthropogenic very short-lived species to stratospheric bromine
}

\author{
R. Hossaini ${ }^{1}$, M. P. Chipperfield ${ }^{1}$, W. Feng ${ }^{1}$, T. J. Breider ${ }^{1,2}$, E. Atlas ${ }^{3}$, S. A. Montzka ${ }^{4}$, B. R. Miller ${ }^{4}$, F. Moore ${ }^{4}$, and \\ J. Elkins ${ }^{4}$ \\ ${ }^{1}$ Institute for Climate and Atmospheric Science, School of Earth and Environment, University of Leeds, Leeds, UK \\ ${ }^{2}$ School of Engineering and Applied Sciences, Harvard University, Cambridge, USA \\ ${ }^{3}$ Rosenstiel School of Marine and Atmospheric Science, University of Miami, Miami, USA \\ ${ }^{4}$ Earth System Research Laboratory, National Oceanic and Atmospheric Administration, Boulder, Colorado, USA
}

Correspondence to: R. Hossaini (r.hossaini@see.leeds.ac.uk)

Received: 19 July 2011 - Published in Atmos. Chem. Phys. Discuss.: 24 August 2011

Revised: 20 December 2011 - Accepted: 22 December 2011 - Published: 5 January 2012

\begin{abstract}
We have used a global three-dimensional chemical transport model to quantify the impact of the very short-lived substances (VSLS) $\mathrm{CHBr}_{3}, \mathrm{CH}_{2} \mathrm{Br}_{2}, \mathrm{CHBr}_{2} \mathrm{Cl}$, $\mathrm{CHBrCl}_{2}, \mathrm{CH}_{2} \mathrm{BrCl}$ and $\mathrm{C}_{2} \mathrm{H}_{5} \mathrm{Br}$ on the bromine budget of the stratosphere. Atmospheric observations of these gases allow constraints on surface mixing ratios that, when incorporated into our model, contribute $\sim 4.9-5.2$ parts per trillion (ppt) of inorganic bromine $\left(\mathrm{Br}_{\mathrm{y}}\right)$ to the stratosphere. Of this total, $\sim 76 \%$ comes from naturally-emitted $\mathrm{CHBr}_{3}$ and $\mathrm{CH}_{2} \mathrm{Br}_{2}$. The remaining species individually contribute modest amounts. However, their accumulated total accounts for up to $\sim 1.2 \mathrm{ppt}$ of the supply and thus should not be ignored. We have compared modelled tropical profiles of a range of VSLS with observations from the recent 2009 NSF HIPPO-1 aircraft campaign. Modelled profiles agree reasonably well with observations from the surface to the lower tropical tropopause layer.

We have also considered the poorly studied anthropogenic VSLS, $\mathrm{C}_{2} \mathrm{H}_{5} \mathrm{Br}, \mathrm{CH}_{2} \mathrm{BrCH}_{2} \mathrm{Br}, n-\mathrm{C}_{3} \mathrm{H}_{7} \mathrm{Br}$ and $i-\mathrm{C}_{3} \mathrm{H}_{7} \mathrm{Br}$. We find the local atmospheric lifetime of these species in the tropical tropopause layer are $\sim 183,603,39$ and 49 days, respectively. These species, particularly $\mathrm{C}_{2} \mathrm{H}_{5} \mathrm{Br}$ and $\mathrm{CH}_{2} \mathrm{BrCH}_{2} \mathrm{Br}$, would thus be important carriers of bromine to the stratosphere if emissions were to increase substantially. Our model shows $\sim 70-73 \%$ and $\sim 80-85 \%$ of bromine from these species in the tropical boundary layer can reach the lower stratosphere.
\end{abstract}

\section{Introduction}

The bromine $(\mathrm{Br})$ budget of the stratosphere is largely controlled by anthropogenic emissions of long-lived source gases (SGs) such as halons (e.g. $\mathrm{CBrF}_{3}$ ) and methyl bromide $\left(\mathrm{CH}_{3} \mathrm{Br}\right)$. These SGs are sufficiently long-lived that tropospheric gradients are small. In recent years, it has been suggested that very short-lived substances (VSLS) of predominately natural origin may provide an additional source of stratospheric inorganic bromine ( $\mathrm{Br}_{\mathrm{y}}^{\mathrm{VSLS}}$ ) (e.g., Sturges et al., 2000; Dorf et al., 2008). The magnitude of this supply is thought to be $6(3-8) \mathrm{ppt}$, representing $\sim 25 \%$ of total stratospheric bromine (Montzka and Reimann et al., 2011).

Natural emissions of VSLS are predominately from marine macro-algae/phytoplankton and show large variability in space and time (e.g., Carpenter et al., 1999). From the tropical marine boundary layer (MBL), troposphere-stratosphere transport can be rapid (hours) in deep convective updrafts. The Western Pacific is a strong convective source region for air entering the tropical tropopause layer (TTL) (e.g., Aschmann et al., 2009). Rapid convective transport allows short-lived SGs to escape oxidation in the troposphere and detrain in the lowermost stratosphere (LMS). Once photolysed, reactive inorganic products (e.g., $\mathrm{BrO}$ ) take part in catalytic ozone $\left(\mathrm{O}_{3}\right)$ depleting cycles (e.g., $\left.\mathrm{BrO}+\mathrm{ClO}\right)$ (e.g., Sinnhuber et al., 2002). The most important natural VSLS are bromoform $\left(\mathrm{CHBr}_{3}\right)$ and dibromomethane $\left(\mathrm{CH}_{2} \mathrm{Br}_{2}\right)$ due to their relatively large emissions and for $\mathrm{CH}_{2} \mathrm{Br}_{2}$ in particular its long local lifetime (e.g., Hossaini et al., 2010). To 
date, most model work has focused on quantifying the stratospheric $\mathrm{Br}_{\mathrm{y}}$ supply from these VSLS (e.g., Hossaini et al., 2010; Liang et al., 2010). These studies estimate a supply of $\sim 2.4$ and $5 \mathrm{ppt}$, respectively. The larger latter value is likely due to the explicit modelling of wet deposition (i.e. removal in precipitation) of soluble $\mathrm{Br}_{\mathrm{y}}$. The assumed uniform 10-day lifetime of $\mathrm{Br}_{\mathrm{y}}$, employed in Hossaini et al. (2010), is likely an underestimate (in some regions) and thus results in too much scavenging of soluble products (e.g., Aschmann et al., 2011). Other model studies have considered dibromochloromethane $\left(\mathrm{CHBr}_{2} \mathrm{Cl}\right)$, bromodichloromethane $\left(\mathrm{CHBrCl}_{2}\right)$ and bromochloromethane $\left(\mathrm{CH}_{2} \mathrm{BrCl}\right)$ in addition (e.g., Warwick et al., 2006; Schofield et al., 2011). Warwick et al. (2006) reported a total $\mathrm{Br}_{\mathrm{y}}^{\mathrm{VSLS}}$ contribution of 6-7 ppt from these species. Variation in the calculated contribution of VSLS is expected due to different treatment of emissions and transport processes (Hoyle et al., 2011; Feng et al., 2011).

Some VSLS have a predominately anthropogenic source;

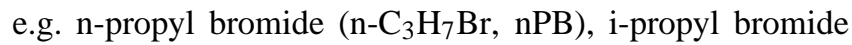
(i- $\mathrm{C}_{3} \mathrm{H}_{7} \mathrm{Br}$, iPB), ethyl bromide $\left(\mathrm{C}_{2} \mathrm{H}_{5} \mathrm{Br}\right)$ and ethylene dibromide $\left(\mathrm{CH}_{2} \mathrm{BrCH}_{2} \mathrm{Br}\right.$, $\left.\mathrm{EDB}\right)$. $\mathrm{nPB}$ is currently used as a replacement compound for some chlorofluorocarbons (CFCs, e.g., CFC-113) and for methyl chloroform $\left(\mathrm{CH}_{3} \mathrm{CCl}_{3}\right)$. It is used for industrial metal degreasing and electronic part cleaning (Montzka and Reimann et al., 2011). $\mathrm{C}_{2} \mathrm{H}_{5} \mathrm{Br}$ is used in chemical synthesis, as a refrigerant and as a flame retardant. Observations show surface mixing ratios of $<0.3 \mathrm{ppt}$ (Low et al., 2003) and 0.09-0.49 ppt (Carpenter et al., 1999). EDB is used as a fumigant and has been observed at $\sim 5 \mathrm{ppt}$ and 1 ppt in urban areas (Pratt et al., 2000) and the South Pole (Khalil and Rasmussen, 1985), respectively.

In general these minor VSLS are poorly studied and observations are sparse. Laube et al. (2008) have suggested unidentified peaks in their chromatogram from air sampled at $15.2 \mathrm{~km}$ point towards the presence of $\mathrm{C}_{2} \mathrm{H}_{5} \mathrm{Br}, \mathrm{nPB}$ and EDB. These balloon-borne measurements were made in 2005 in the tropics (Teresina, Brazil). These species are estimated to currently contribute $<0.2 \mathrm{ppt}$ of organic bromine in the TTL region (Montzka and Reimann et al., 2011). Quantifying the present-day contribution of these unregulated anthropogenic VSLS on stratospheric $\mathrm{Br}_{\mathrm{y}}$ is important. In this study we have used a global model constrained by observations to

1. Evaluate modelled distribution of bromine-containing VSLS with new observations from the 2009 NSF HIAPER Pole-to-Pole (HIPPO-1) campaign (Wofsy et al., 2011) and ongoing National Oceanic and Atmospheric Administration/Earth System Research Laboratory (NOAA/ESRL) measurement programs.

2. Calculate the local atmospheric lifetimes of poorly studied $\mathrm{C}_{2} \mathrm{H}_{5} \mathrm{Br}, \mathrm{CH}_{2} \mathrm{BrCH}_{2} \mathrm{Br}, \mathrm{n}-\mathrm{C}_{3} \mathrm{H}_{7} \mathrm{Br}$ and $\mathrm{i}-\mathrm{C}_{3} \mathrm{H}_{7} \mathrm{Br}$.

3. Estimate $\mathrm{Br}_{\mathrm{y}}^{\mathrm{VSLS}}$ in the tropical lower stratosphere. Given convection is an uncertainty in a global model, we examine the sensitivity of $\mathrm{Br}_{\mathrm{y}}^{\mathrm{VSLS}}$ to two treatments of convection.

Section 2 describes the model, improvements on our previous model set up (Hossaini et al., 2010) and experiments performed. Results are presented in Sect. 3 along with a description of the NSF HIPPO-1 data. Conclusions and recommendations for future work are discussed in Sect. 4.

\section{Model description}

TOMCAT/SLIMCAT is a three-dimensional (3-D) chemical transport model (CTM) described in detail by Chipperfield (2006). For this study we ran the CTM with 38 hybrid $\sigma-p$ vertical levels extending from the surface to $\sim 35 \mathrm{~km}$ and with a resolution of $5.6^{\circ} \times 5.6^{\circ}$. The offline model is forced by analysed winds taken from the European Centre for MediumRange Weather Forecasts (ECMWF) ERA-Interim reanalysis. The CTM includes an online parameterisation of cumulus convection based on the Tiedtke (1989) mass flux scheme (Stockwell and Chipperfield, 1998). This CTM set up is described in Hossaini et al. (2010) and has been shown to simulate the transport/chemistry of short-lived tracers reasonably well.

We have made two improvements compared to Hossaini et al. (2010). First, as model convection is an uncertainty, we also now include an additional approach to the Tiedtke (1989) mass flux scheme. Here the CTM can be forced with ERA-Interim archived convective updraft/downdraft mass fluxes and detrainment rates (Feng et al., 2011). Second, we model the wet deposition of soluble $\mathrm{Br}_{\mathrm{y}}$ in both large-scale dynamic and also convective precipitation (Giannakopoulos et al., 1999). The fraction of $\mathrm{Br}_{\mathrm{y}}$ available for wet deposition is altitude-dependent. Here we partition $\mathrm{Br}_{\mathrm{y}}$ among nonsoluble products (e.g. $\mathrm{BrO}$ ) and soluble $\mathrm{HBr}$ using a $\mathrm{HBr}: \mathrm{Br}_{\mathrm{y}}$ ratio from a previous full chemistry TOMCAT integration (Breider et al., 2010).

In this study we include 9 bromine-containing VSLS SG tracers (see Table 1) and the following long-lived species: methyl bromide $\left(\mathrm{CH}_{3} \mathrm{Br}\right)$, Halon-1211 (H1211, $\left.\mathrm{CF}_{2} \mathrm{BrCl}\right)$, Halon-1301 (H1301, $\left.\mathrm{CBrF}_{3}\right)$ and Halon-2402 $\left(\mathrm{H} 2402, \mathrm{C}_{2} \mathrm{Br}_{2} \mathrm{~F}_{4}\right)$. The CTM here also includes methyl iodide $\left(\mathrm{CH}_{3} \mathrm{I}\right)$ and an idealised tracer with a $6 \mathrm{~h}$ lifetime (i6hr). These shorter lived species are useful for assessing troposphere-stratosphere transport in modelled convection. The model surface mixing ratio of most SGs are constrained by HIPPO- 1 observations in the tropical regions. For $\mathrm{CHBrCl}_{2}$ and $\mathrm{CH}_{2} \mathrm{BrCl}$ the model is constrained by the estimated MBL mixing ratios, based on a compilation of observations, provided in Law and Sturges et al. (2007). Observations of EDB, nPB and iPB are sparse. For these gases, the model surface mixing ratio cannot be constrained by observations and thus have an arbitrary value at the surface. Therefore, these gases are not considered in the calculated $\mathrm{Br}_{\mathrm{y}}^{\mathrm{VSLS}}$. 
Table 1. Model Br-containing source gases and assumed surface volume mixing ratio $\left(\mathrm{vmr} \mathrm{ppt}^{-1}\right)$.

\begin{tabular}{llll}
\hline Source gas & Formula & Source & Surface vmr \\
\hline Methyl bromide & $\mathrm{CH}_{3} \mathrm{Br}$ & $\mathrm{N}(\mathrm{A})$ & $7.50^{\mathrm{a}}$ \\
Halon 1211 (H1211) & $\mathrm{CF}_{2} \mathrm{BrCl}$ & $\mathrm{A}$ & $4.23^{\mathrm{a}}$ \\
Halon 1301 (H1301) & $\mathrm{CBrF}_{3}$ & $\mathrm{~A}$ & $3.15^{\mathrm{a}}$ \\
Halon 2402 (H2402) & $\mathrm{C}_{2} \mathrm{Br}_{2} \mathrm{~F}_{4}$ & $\mathrm{~A}$ & $0.46^{\mathrm{a}}$ \\
Bromoform & $\mathrm{CHBr}_{3}$ & $\mathrm{~N}(\mathrm{~A})$ & $1.20^{\mathrm{a}, \mathrm{b}}$ \\
Dibromomethane & $\mathrm{CH}_{2} \mathrm{Br}_{2}$ & $\mathrm{~N}$ & $1.0^{\mathrm{a}, \mathrm{b}}$ \\
Dibromochloromethane & $\mathrm{CHBr}_{2} \mathrm{Cl}$ & $\mathrm{N}(\mathrm{A})$ & $0.20^{\mathrm{a}}$ \\
Bromodichloromethane & $\mathrm{CHBrCl}_{2}$ & $\mathrm{~N}(\mathrm{~A})$ & $0.33^{\mathrm{c}}$ \\
Bromochloromethane & $\mathrm{CH}_{2} \mathrm{BrCl}$ & $\mathrm{N}$ & $0.47^{\mathrm{c}}$ \\
Ethyl bromide & $\mathrm{C}_{2} \mathrm{H}_{5} \mathrm{Br}$ & $\mathrm{A}$ & $0.30^{\mathrm{a}}$ \\
Ethylene dibromide (EDB) & $\mathrm{CH}_{2} \mathrm{BrCH} \mathrm{Hr}_{2} \mathrm{Br}$ & $\mathrm{A}$ & - \\
n-propyl bromide (nPB) & $\mathrm{n}-\mathrm{C}_{3} \mathrm{H}_{7} \mathrm{Br}$ & $\mathrm{A}$ & - \\
i-propyl bromide (iPB) & $\mathrm{i}-\mathrm{C}_{3} \mathrm{H}_{7} \mathrm{Br}$ & $\mathrm{A}$ & - \\
\hline
\end{tabular}

${ }^{\text {a }}$ Best fit to HIPPO observations (this work).

b Best fit to observations (Hossaini et al., 2010).

${ }^{\mathrm{c}}$ Estimated tropical MBL mixing ratio (Law and Sturges et al., 2007).

Source data both natural $(\mathrm{N})$ and/or anthropogenic (A) taken from Law and Sturges et al. (2007).

There is significant uncertainty in the surface emissions of natural and anthropogenic VSLS. There is likely to be considerable spatial variation in the location of emission (e.g., Law and Sturges et al., 2007). Warwick et al. (2006) found significant variation in modelled $\mathrm{CHBr}_{3}$ profiles depending on source region. While use of spatially varying emissions for $\mathrm{CHBr}_{3}$ and $\mathrm{CH}_{2} \mathrm{Br}_{2}$ is possible (e.g., Liang et al., 2010), emissions of minor VSLS (e.g., $\mathrm{CHBr}_{2} \mathrm{Cl}$ ) are poorly quantified. For simplicity, and to overcome some of this uncertainty, in the model runs presented here we do not specify emissions but instead we overwrite the surface volume mixing ratio (vmr) of the halogenated source gases. The surface vmr is constant with latitude and longitude within the tropics and is scaled so that the model gives good agreement with observation in the free troposphere, where available. This approximation is better for longer-lived species which will be mixed by transport processes and are the species which are potentially more important for transport to the stratosphere. For VSLS, our approach will not capture potential hot spot regions where surface fluxes are relatively large.

Loss of SG occurs via oxidation by $\mathrm{OH}$ and photolysis. Rate constants and absorption cross sections are taken from Sander et al. (2006) where available. SG degradation is assumed to release $\mathrm{Br}_{\mathrm{y}}$ immediately (i.e. $\mathrm{CHBr}_{3}+\mathrm{OH} \rightarrow 3 \times \mathrm{Br}_{\mathrm{y}}$ ). This assumption, which ignores any organic product gases (e.g. $\mathrm{CBr}_{2} \mathrm{O}$ ), has been shown to be good for $\mathrm{CHBr}_{3}$ and $\mathrm{CH}_{2} \mathrm{Br}_{2}$ (Hossaini et al., 2010). Henry's law constants needed for calculating the wet deposition of soluble $\mathrm{Br}_{\mathrm{y}}$ products are taken from Law and Sturges et al. (2007).

We have performed 2 model simulations; run $\mathrm{S}_{\text {diagnosed }}$ where we diagnose convective transport and run $S_{\text {archived }}$ where convective transport is forced with archived mass fluxes. Both simulations were initialised on 1 January 2005 and run for 3 years.

\section{Results and discussion}

\subsection{Modelled tracer profiles}

The modelled source gas profiles of $\mathrm{CH}_{3} \mathrm{Br}, \mathrm{H} 1211, \mathrm{H} 1301$, $\mathrm{H} 2402, \mathrm{CHBr}_{3}, \mathrm{CH}_{2} \mathrm{Br}_{2}, \mathrm{CHBr}_{2} \mathrm{Cl}, \mathrm{C}_{2} \mathrm{H}_{5} \mathrm{Br}$ and $\mathrm{CH}_{3} \mathrm{I}$ are shown in Fig. 1. We compare with aircraft observations in the tropics $\left( \pm 20^{\circ}\right)$ from the recent NSF HIPPO-1 campaign (January 2009, http://hippo.ornl.gov/). The HIPPO program is an ongoing series of global aircraft measurements spanning global latitudes from the near North Pole to coastal Antarctica. The NSF Gulfstream V aircraft is used to sample the atmosphere from the surface to $\sim 14 \mathrm{~km}$. Numerous trace gases have been measured including the greenhouse gases $\mathrm{CO}_{2}, \mathrm{CH}_{4}, \mathrm{~N}_{2} \mathrm{O}$ and also $\mathrm{CO}, \mathrm{SF}_{6}, \mathrm{CFCs}$, VSLS etc. (Wofsy et al., 2011). Whole air samples, collected in stainless steel and glass flasks, from 5 flights were analysed using gas chromatography/mass spectrometry (GC-MS) in two different laboratories; the University of Miami and NOAA/ESRL (Schauffler et al., 1999). Mixing ratios reported by the Miami laboratory were multiplied by factors of $0.90,0.94,0.98,0.94,0.81$ and 1.01 for $\mathrm{CH}_{3} \mathrm{Br}, \mathrm{H} 1301$, $\mathrm{H} 1211, \mathrm{H} 2402, \mathrm{CH}_{2} \mathrm{Br}_{2}$ and $\mathrm{CHBr}_{3}$, respectively, to be consistent with the NOAA/ESRL laboratory calibration scale.

We also consider January 2009 monthly mean surface observations from an ongoing NOAA/ESRL program at three sites in the Pacific Basin; American Samoa (SMO, $14.3^{\circ} \mathrm{S}, 170.6^{\circ} \mathrm{W}$ ), Mauna Loa (MLO, $19.5^{\circ} \mathrm{N}, 155.6^{\circ} \mathrm{W}$ ) and Cape Kumukahi (KUM, $19.5^{\circ} \mathrm{N}, 154.8^{\circ} \mathrm{W}$ ). Whole air samples were collected weekly into paired steel or glass flasks and have been analysed (GC-MS) in the same laboratory as the HIPPO measurements. Aircraft observations up to $\sim 6.5 \mathrm{~km}$ a.s.l. over Raratonga $\left(21.5^{\circ} \mathrm{N}, 160.0^{\circ} \mathrm{W}\right)$ are also considered. These additional observations are consistent in space/time with the observations from HIPPO. Further description of the NOAA/ESRL surface network can be obtained in Montzka et al. (2003). For this comparison, the model is averaged over the flight days and also in space. The TTL base is defined as the level of main convective outflow $(\sim 12 \mathrm{~km})$ and the top as the cold-point tropopause (CPT, $\sim 17 \mathrm{~km}$ ). The upper TTL is defined as beyond the level of zero radiative heating, where slow radiatively-driven ascent dominates over convective mixing (Law and Sturges et al., 2007).

Both runs $\mathrm{S}_{\text {diagnosed }}$ and $\mathrm{S}_{\text {archived }}$ show good agreement with observations. Model profiles of $\mathrm{CHBr}_{3}$ and $\mathrm{CH}_{2} \mathrm{Br}_{2}$ give good agreement when constrained by $1-1.2 \mathrm{ppt}$ at the surface. This is consistent with previous aircraft comparisons (Hossaini et al., 2010). The profiles indicate $\sim 0.5$ and $0.8 \mathrm{ppt}$ of $\mathrm{CHBr}_{3}$ and $\mathrm{CH}_{2} \mathrm{Br}_{2}$ in the lower TTL, respectively. This 


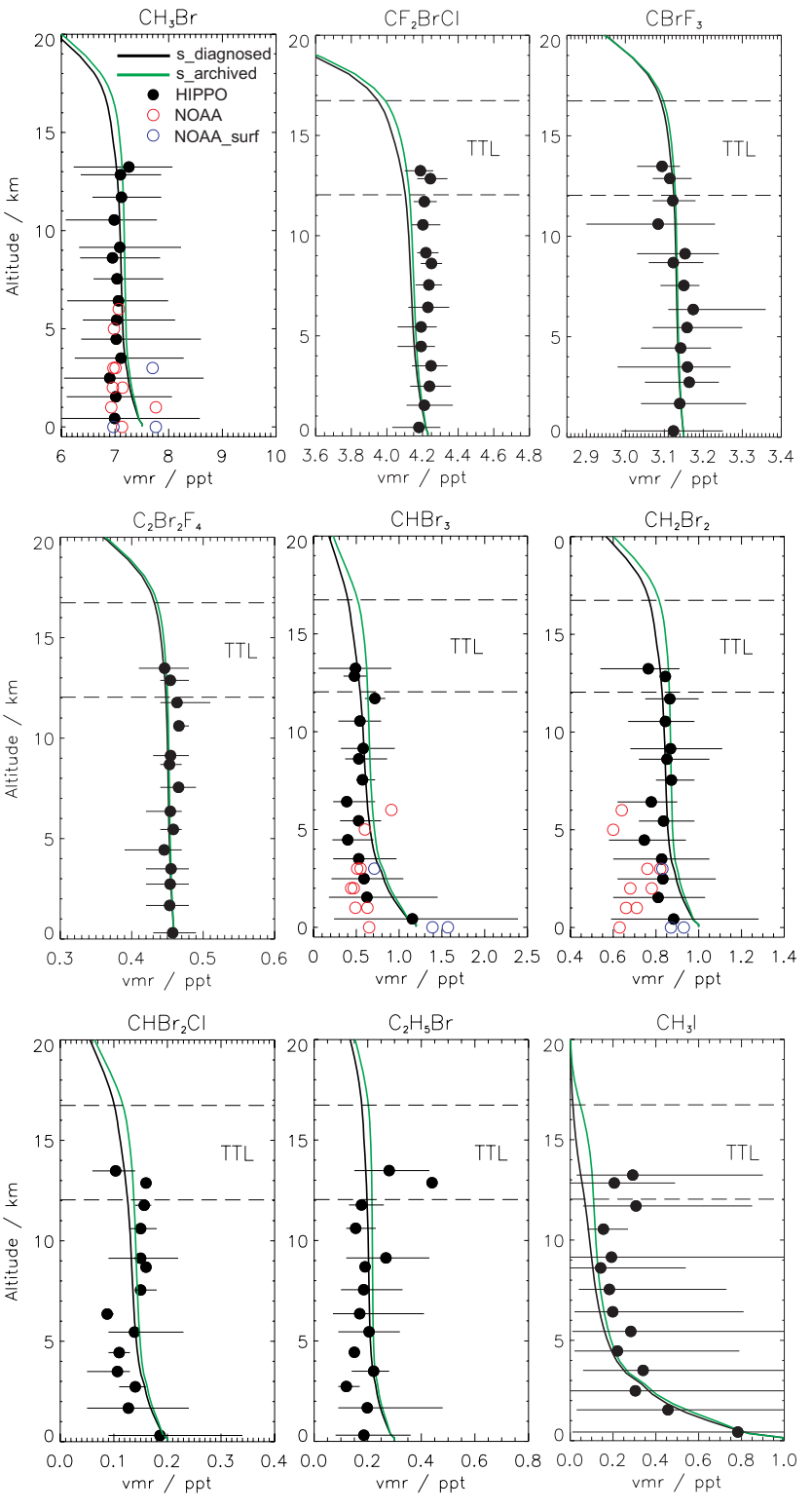

Fig. 1. Mean observed and modelled tropical $\left( \pm 20^{\circ}\right)$ mixing ratio (ppt) of (a) $\mathrm{CH}_{3} \mathrm{Br}$, (b) $\mathrm{CF}_{2} \mathrm{BrCl}$ (H1211), (c) $\mathrm{CBrF}_{3}$ (H1301), (d) $\mathrm{C}_{2} \mathrm{Br}_{2} \mathrm{~F}_{4}(\mathrm{H} 2402)$, (e) $\mathrm{CHBr}_{3}$, (f) $\mathrm{CH}_{2} \mathrm{Br}_{2}$, (g) $\mathrm{CHBr}_{2} \mathrm{Cl}$, (h) $\mathrm{C}_{2} \mathrm{H}_{5} \mathrm{Br}$ and (i) $\mathrm{CH}_{3} \mathrm{I}$. Observations (filled circles) taken from the NSF HIPPO-1 campaign (January 2009). Horizontal bars denote min-max variability of observations at given level. Open circles denote observations during January 2009 from three NOAA/ESRL surface sites (blue points from SMO, $14.3^{\circ} \mathrm{S}$, $170.6^{\circ} \mathrm{W}, 77 \mathrm{~m}$ a.s.1.; $\quad$ MLO, $19.5^{\circ} \mathrm{N}, 155.6^{\circ} \mathrm{W}, 3397 \mathrm{~m}$ a.s.1.; KUM, $19.5^{\circ} \mathrm{N}, 154.8^{\circ} \mathrm{W}, 3 \mathrm{~m}$ a.s.l.) or from vertical profiles (red points sampled over Raratonga, $21^{\circ} \mathrm{S}, 159.8^{\circ} \mathrm{W}$ ).

is consistent with the lower TTL (12-14 km) mean mixing ratio and range of 0.61(0.3-1.1) ppt and 0.92(0.77-1.15) ppt reported by Montzka and Reimann et al. (2011) and based on a compilation of previous observations. The HIPPO-
1 observations show $\mathrm{CHBr}_{2} \mathrm{Cl}$ mixing ratios of $0.1-0.2 \mathrm{ppt}$ in the lower TTL. This is again consistent with previously observed mixing ratios of $0.1(0.06-0.15) \mathrm{ppt}$ (Montzka and Reimann et al., 2011). The anthropogenic short-lived substance, $\mathrm{C}_{2} \mathrm{H}_{5} \mathrm{Br}$, was also detected in the TTL $(\sim 0.4 \mathrm{ppt})$. $\mathrm{nPB}$ was below the detection limit of $\sim 0.5 \mathrm{ppt}$.

Overall, run $S_{\text {archived }}$ shows more tracer transported to the upper TTL. This can be expected given the archived mass fluxes show strong convection in the tropics (e.g., Hoyle et al., 2011; Feng et al., 2011). However, the averaged profiles in Fig. 1 show only small differences between runs $S_{\text {diagnosed }}$ and $S_{\text {archived }}$, particularly for the relatively longerlived gases for which vertical transport in convective cells is less important. The differences between the two model runs is discussed further in Sect. 3.2.

\subsection{Archived versus diagnosed convection}

The implementation of 6-hourly ECMWF archived convective mass fluxes in the TOMCAT CTM is described in Feng et al. (2011). Here we use observations of short-lived halogen species in the mid-upper troposphere to examine the performance of these fluxes compared to fluxes diagnosed within the model. The archived convective updraft mass flux shows non-zero values at $100 \mathrm{hPa}(\sim 16.5 \mathrm{~km})$. The diagnosed convection typically does not extend above $200 \mathrm{hPa}$ $(\sim 12.5 \mathrm{~km})$ and this does not capture deep convective events (Feng et al., 2011). To investigate the differences between runs $S_{\text {diagnosed }}$ and $\mathrm{S}_{\text {archived }}$ further, we also consider $\mathrm{CH}_{3} \mathrm{I}$; a trace gas with a local lifetime of $\sim 7$ days and thus shorter lived than any of the bromine-containing VSLS previously discussed (Law and Sturges et al., 2007). Figure 2 shows modelled profiles of $\mathrm{CH}_{3} \mathrm{I}$ in the tropics from both runs $S_{\text {diagnosed }}$ and $S_{\text {archived }}$ versus observations made on board the DC8 aircraft during the 2007 NASA TC4 campaign (see Hossaini et al. (2010) for campaign description).

In Fig. 2, the difference between the two convective set ups is more pronounced than for the longer-lived brominecontaining VSLS. With an assumed uniform surface mixing ratio of $1 \mathrm{ppt}$ in the tropics, both runs $S_{\text {diagnosed }}$ and $\mathrm{S}_{\text {archived }}$ give reasonable agreement with the observations. A surface mixing ratio of $1 \mathrm{ppt}$ is within the estimated range of $0.3-1.9 \mathrm{ppt}$ for the marine boundary layer reported by Montzka and Reimann et al. (2011). Run $S_{\text {archived shows }}$ significantly more $\mathrm{CH}_{3} \mathrm{I}$ in the TTL. This appears to provide a better fit to observations, particularly for flights on the 5/8 August 2007 (see Fig. 2).

The zonally averaged mixing ratio of the idealised tracer with a $6 \mathrm{~h}$ lifetime (i6hr), $\mathrm{CH}_{3} \mathrm{I}, \mathrm{CHBr}_{3}$ and $\mathrm{CH}_{2} \mathrm{Br}_{2}$ at the approximate base of the TTL $(\sim 200 \mathrm{mb})$ and the tropical cold point tropopause (CPT, $\sim 100 \mathrm{mb}$ ) is shown in Fig. 3 . i6hr was initialised at $1 \mathrm{ppt}$ at the surface at the start of the simulation. Run $S_{\text {archived }}$ transports more tracer to higher altitudes in all seasons with the largest difference between runs $S_{\text {diagnosed }}$ and $S_{\text {archived }}$ being for the relatively shortest 

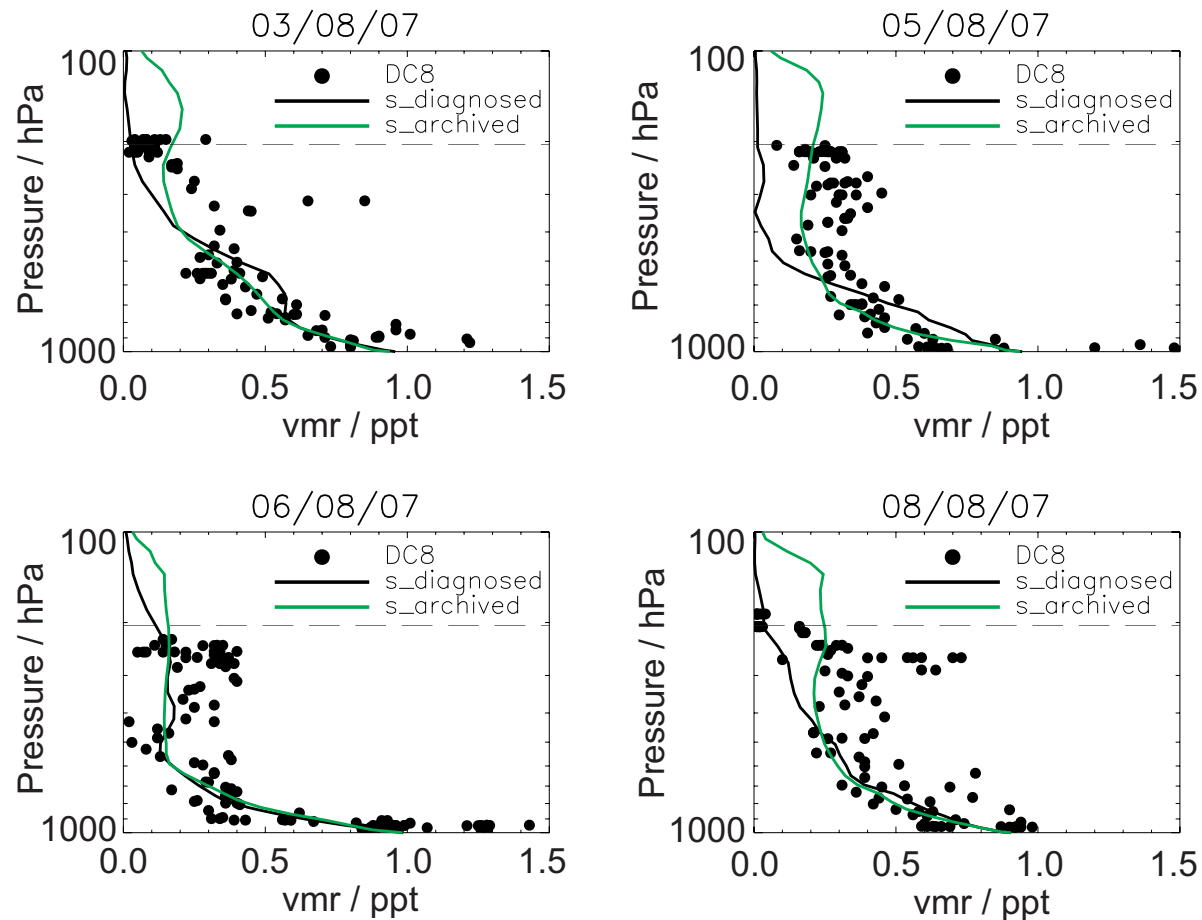

Fig. 2. Comparison of modelled $\mathrm{CH}_{3} \mathrm{I}$ profiles with observations made on board 4 DC8 flights during the NASA TC4 campaign (July-August 2007, http://www.espo.nasa.gov/tc4/). The CTM profiles are from both runs $S_{\text {diagnosed }}$ and $S_{\text {archived }}$. The approximate base of the TTL is indicated with a dashed line.
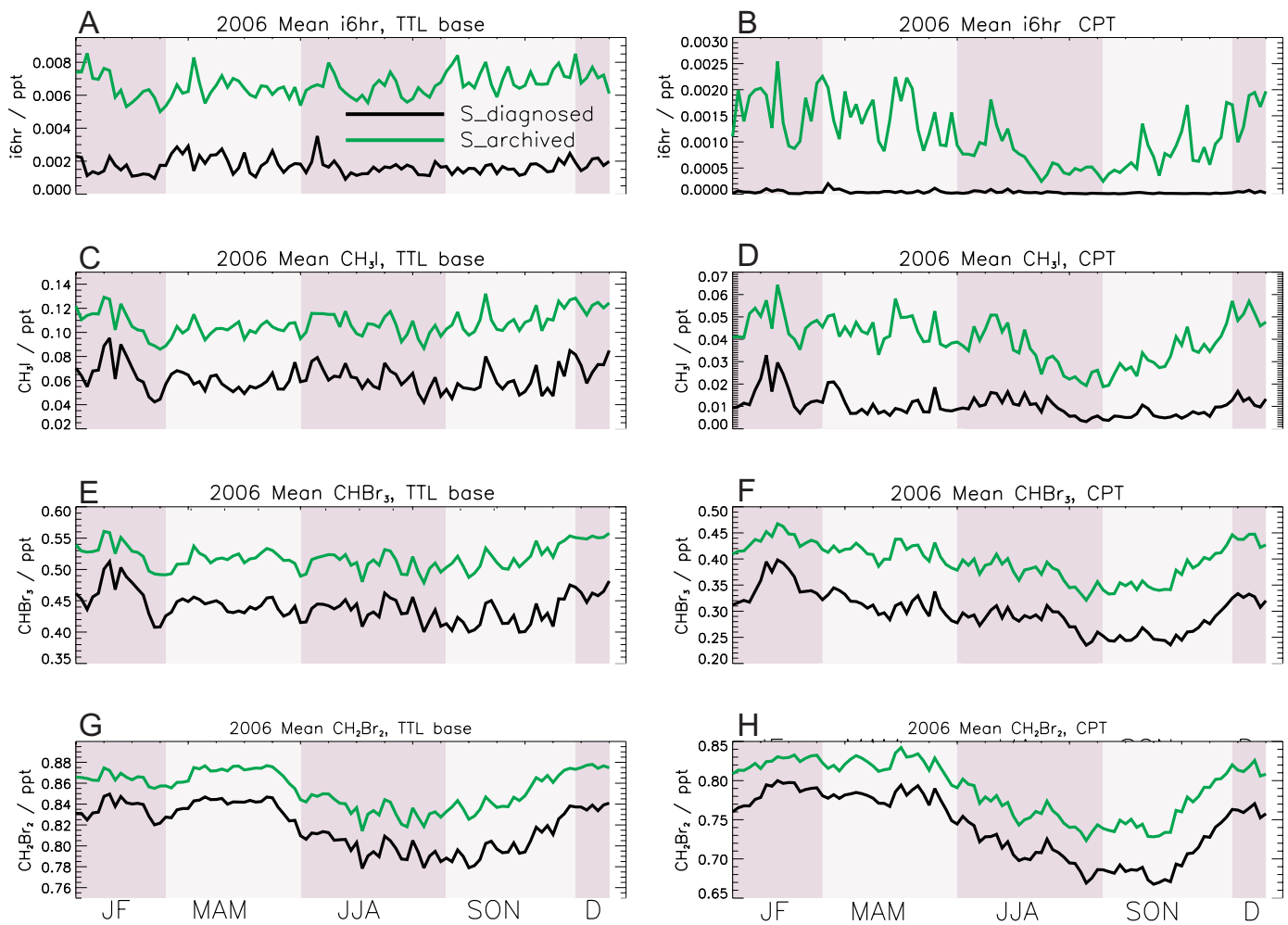

Fig. 3. Zonally averaged volume mixing ratio of $(\mathbf{A}, \mathbf{B})$ i6hr, $(\mathbf{C}, \mathbf{D}) \mathrm{CH}_{3} \mathrm{I},(\mathbf{E}, \mathbf{F}) \mathrm{CHBr}_{3}$ and $(\mathbf{G}, \mathbf{H}) \mathrm{CH}_{2} \mathrm{Br}_{2}$ as a function of time (2006) at the TTL base and the tropical cold point tropopause, respectively, for CTM runs $S_{\text {diagnosed }}$ and $S_{\text {archived }}$. 


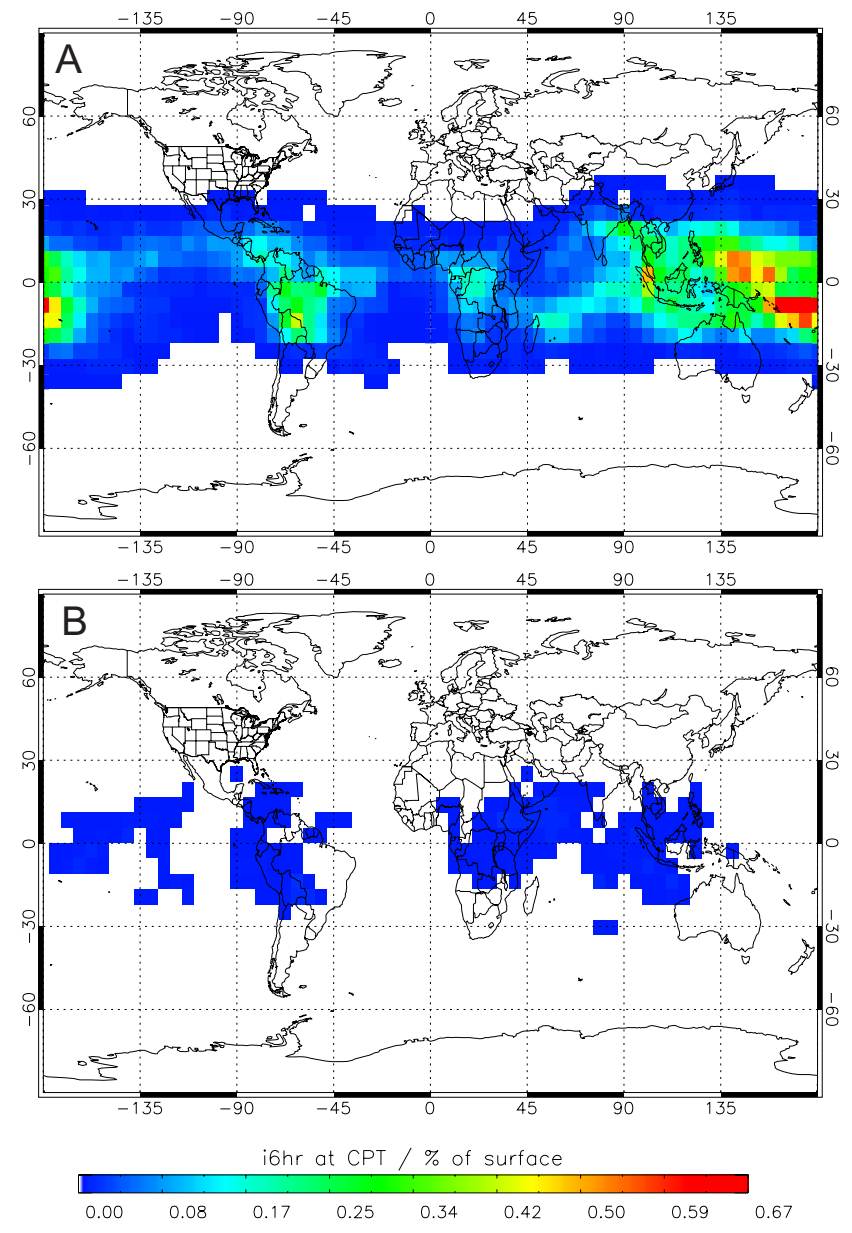

Fig. 4. Percentage (\%) of the surface mixing ratio of the idealised tracer (i6hr) at the cold point tropopause from (A) $S_{\text {archived and }}$ (B) $\mathrm{S}_{\text {diagnosed }}$. Initial uniform surface vmr of $1 \mathrm{ppt}$.

lived species (e.g. i6hr, $\mathrm{CH}_{3} \mathrm{I}$ ). For $\mathrm{CH}_{3} \mathrm{I}, \mathrm{CPT}$ mixing ratios are within the estimated range of $0.02-0.18 \mathrm{ppt}$ reported by Law and Sturges et al. (2007) for the tropical upper troposphere. The $\mathrm{CPT} \mathrm{CH}_{3} \mathrm{I}$ mixing ratios from $\mathrm{S}_{\text {diagnosed }}$ are up to $\sim 6 \times$ lower. For $\mathrm{CHBr}_{3}$ and $\mathrm{CH}_{2} \mathrm{Br}_{2}$, both the TTL and CPT mixing ratios are less sensitive to the choice of convection scheme.

Figure 4 shows the annual mean mixing ratio of i6hr at the CPT for runs $S_{\text {diagnosed }}$ and $S_{\text {archived }}$. Clearly, stronger convection with run $\mathrm{S}_{\text {archived }}$ leads to a larger modelled mixing ratio at this level. Here, the strongest convection occurs over the Western Pacific, indicating a strong source region for the troposphere-stratosphere of VSLS - consistent with Aschmann et al. (2009). For studying the tropospherestratosphere transport of relatively shorter lived gases (including species whose lifetime is equal to or less than that of $\mathrm{CH}_{3} \mathrm{I}$ ), the choice of convection scheme is clearly important.

\subsection{Source gas local lifetimes}

We have calculated the local lifetimes $\left(\tau_{\text {local }}\right)$ of source gases in the model using:

$\tau_{\text {local }}^{-1}=\tau_{\mathrm{OH}}^{-1}+\tau_{h v}^{-1}$

Here $\tau_{\mathrm{OH}}$ and $\tau_{h v}$ are the lifetimes with respect to $\mathrm{OH}$ oxidation and photolysis, respectively. The annual tropical mean lifetimes of $\mathrm{C}_{2} \mathrm{H}_{5} \mathrm{Br}$, EDB, nPB and iPB are shown in Fig. 5. Note, the equivalent lifetime plots of $\mathrm{CHBr}_{3}$ and $\mathrm{CH}_{2} \mathrm{Br}_{2}$ can be found in Hossaini et al. (2010).

For these species $\mathrm{OH}$ oxidation is the dominant sink in the troposphere. For $\mathrm{C}_{2} \mathrm{H}_{5} \mathrm{Br}$, the simulated local lifetime is $\sim 18$ days at the surface and up to $\sim 183$ days in the TTL. Similarly for EDB, the local lifetime is $\sim 30$ and up to $\sim 603$ days at the surface and in the TTL, respectively. The long local lifetime in the cold TTL is due to the strong temperature dependence of the $\mathrm{OH}$ sink reaction. Once in the TTL, $\mathrm{C}_{2} \mathrm{H}_{5} \mathrm{Br}$ and EDB are thus potentially important carriers of bromine to the stratosphere.

It is clear that local lifetimes of VSLS can vary substantially with altitude. The simulated local lifetime of nPB is $\sim 6$ days at the surface and up to 38 days in the TTL. Similarly for iPB, we find local lifetimes of 8 (surface) and 49 days (TTL). For these species with relatively shorter lifetimes at the surface, rapid convective transport to the TTL is likely required for their source gas contribution to be significant. The tropospheric mean local lifetimes of VSLS have also been calculated. These values are shown in Table 2 .

Our simulated local lifetimes in the TTL vary from those quoted in the recent World Meteorological Organisation (WMO) Assessment Report (Montzka and Reimann et al., 2010). The reason for this is that the WMO values are based on $\mathrm{OH}$ loss rates calculated using a uniform tropospheric $\mathrm{OH}$ concentration $\left(1 \times 10^{6}\right.$ molecules $\left.\mathrm{cm}^{-3}\right)$ and for a temperature of $275 \mathrm{~K}$, i.e. representative of the surface. The simulated local lifetimes here are derived using a spatially/temporally varying $\mathrm{OH}$ field (and photolysis) and can be quoted as a function of temperature/altitude. A direct comparison of the two is therefore not appropriate, but if a gas is sufficiently long-lived to be transported away from the surface then the WMO lifetimes may not be applicable.

\subsection{Modelled total bromine}

The modelled source gas injection (SGI), product gas injection (PGI) and total bromine (SGI + PGI) for VSLS, $\mathrm{CH}_{3} \mathrm{Br}$ and the halons is shown in Table 2. SGI is the organic bromine resulting from direct transport of a source gas to the lower stratosphere (i.e. for $\mathrm{CH}_{2} \mathrm{Br}_{2}, 2 \times$ the $\mathrm{SG}$ mixing ratio at the tropopause). Similarly, PGI is the contribution from the inorganic products, formed following SG degradation.

The total bromine contribution from major VSLS $\mathrm{CHBr}_{3}$ and $\mathrm{CH}_{2} \mathrm{Br}_{2}$ is $\sim 2.09$ and $1.69 \mathrm{ppt}$ (tropical mean), respectively from simulation $\mathrm{S}_{\text {diagnosed }}$. The contribution is 

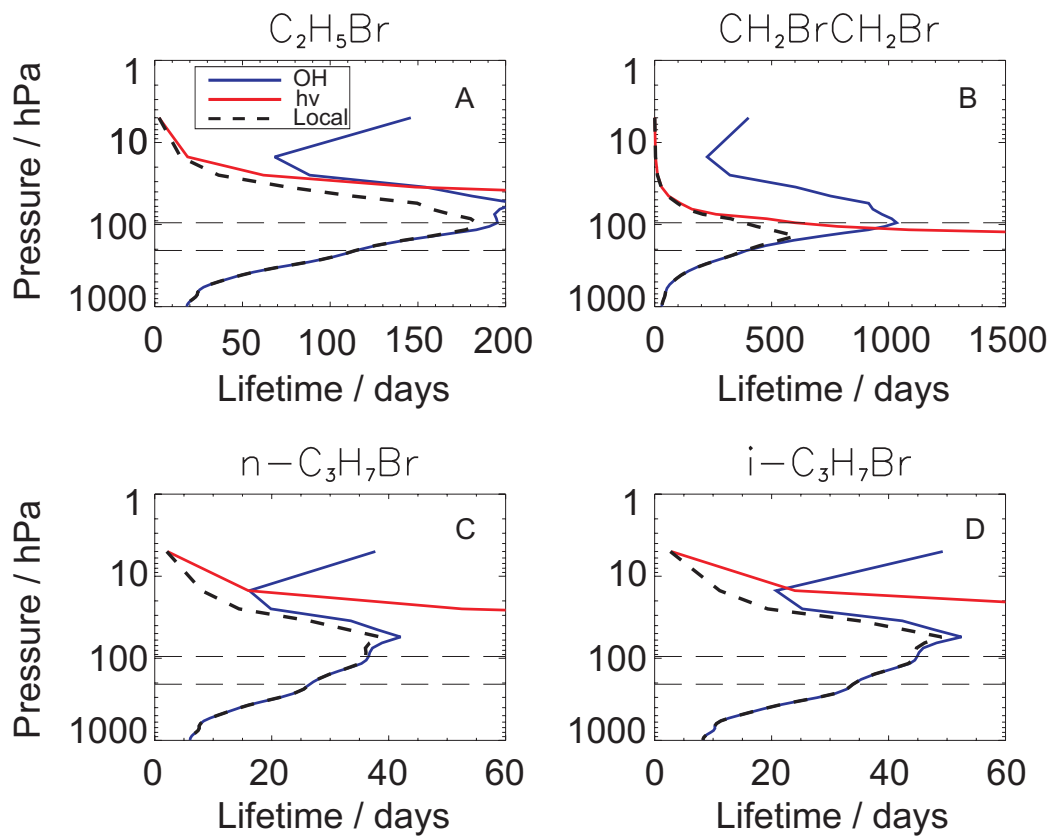

Fig. 5. Modelled mean local tropical lifetime (days) with respect to $\mathrm{OH}$ oxidation, photolysis and total for $(\mathbf{A}) \mathrm{C}_{2} \mathrm{H}_{5} \mathrm{Br},(\mathbf{B}) \mathrm{CH}_{2} \mathrm{BrCH} \mathrm{Br}_{2}$, (C) $\mathrm{n}-\mathrm{C}_{3} \mathrm{H}_{7} \mathrm{Br}$ and (D) $\mathrm{i}-\mathrm{C}_{3} \mathrm{H}_{7} \mathrm{Br}$. Horizontal lines denote the approximate TTL.

Table 2. 2007 tropical mean source gas injection (SGI), product gas injection (PGI) and total bromine (SGI + PGI) loading from VSLS, $\mathrm{CH}_{3} \mathrm{Br}$ and the halons in the lower stratosphere. Results are from simulations $\mathrm{S}_{\text {diagnosed }}$ and $\mathrm{S}_{\text {archived }}$.

\begin{tabular}{lcccccc}
\hline & \multicolumn{2}{c}{ SGI $(\mathrm{ppt})$} & \multicolumn{2}{c}{ PGI (ppt) } & \multicolumn{2}{c}{ Total $^{\mathrm{b}}$} \\
Species $^{\mathrm{a}}$ & $\mathrm{S}_{\text {diag }}$ & $\mathrm{S}_{\text {arch }}$ & $\mathrm{S}_{\text {diag }}$ & $\mathrm{S}_{\text {arch }}$ & $\mathrm{S}_{\text {diag }}$ & $\mathrm{S}_{\text {arch }}$ \\
\hline $\mathrm{CH}_{3} \mathrm{Br}$ & 6.77 & 6.90 & 0.33 & 0.29 & $7.11[95]$ & $7.19[96]$ \\
$\mathrm{H} 1211$ & 3.94 & 3.98 & 0.21 & 0.19 & $4.15[98]$ & $4.17[99]$ \\
$\mathrm{H} 1301$ & 3.09 & 3.09 & 0.04 & 0.04 & $3.13[99]$ & $3.13[99]$ \\
$\mathrm{H} 2402$ & 0.86 & 0.87 & 0.04 & 0.04 & $0.90[98]$ & $0.91[99]$ \\
$\mathrm{CHBr}_{3}\{21\}$ & 1.06 & 1.41 & 1.03 & 0.91 & $2.09[58]$ & $2.32[64]$ \\
$\mathrm{CH}_{2} \mathrm{Br}_{2}\{212\}$ & 1.49 & 1.58 & 0.20 & 0.16 & $1.69[85]$ & $1.74[87]$ \\
$\mathrm{CHBr}_{2} \mathrm{Cl}\{42\}$ & 0.19 & 0.22 & 0.10 & 0.08 & $0.29[73]$ & $0.30[75]$ \\
$\mathrm{CHBrCl}_{2}\{35\}$ & 0.14 & 0.17 & 0.09 & 0.07 & $0.23[70]$ & $0.24[73]$ \\
$\mathrm{CH}_{2} \mathrm{BrCl}\{274\}$ & 0.37 & 0.39 & 0.04 & 0.03 & $0.41[87]$ & $0.42[89]$ \\
$\mathrm{C}_{2} \mathrm{H}_{5} \mathrm{Br}\{72\}$ & 0.17 & 0.19 & 0.04 & 0.03 & $0.21[70]$ & $0.22[73]$ \\
$\mathrm{EDB}\{200\}$ & - & - & - & - & $-[80]$ & $-[85]$ \\
$\mathrm{nPB}\{17\}$ & - & - & - & - & $-[40]$ & $-[50]$ \\
$\mathrm{iPB}\{21\}$ & - & - & - & - & $-[50]$ & $-[60]$ \\
\hline$\sum \mathrm{VSLS}$ & 3.42 & 3.96 & 1.50 & 1.28 & 4.92 & 5.24 \\
$\sum \mathrm{ALL}$ & 18.08 & 18.80 & 2.12 & 1.84 & 20.21 & 20.64 \\
\hline
\end{tabular}

a Values in curly brackets ( \{\} ) give the mean species-weighted tropical tropospheric lifetime (days).

b Values in square brackets ([ ]) give the fraction of total boundary layer bromine reaching the lower stratosphere (\%).

larger (2.32 and $1.74 \mathrm{ppt})$ from simulation $\mathrm{S}_{\text {archived }}$. The larger SGI values from simulation $\mathrm{S}_{\text {archived }}$ are due to deeper model convection from the ECMWF ERA-Interim fields. This allows more rapid tracer transport to the cold TTL where the SG lifetime is relatively longer. As noted previously (see Sect. 3.2), the increased upwelling from sim- ulation $\mathrm{S}_{\text {archived }}$ is most significant for the shortest lived tracers. For $\mathrm{CH}_{3} \mathrm{I}$ (PGI not considered), expressed as a tropical mean, $\sim 1.0 \%$ and $3.6 \%$ of the source gas surface vmr $(1 \mathrm{ppt})$ reaches the lower stratosphere from runs $S_{\text {diagnosed }}$ and $S_{\text {archived }}$, respectively. Run $S_{\text {archived }}$ also experiences more spatially widespread convection and thus also 


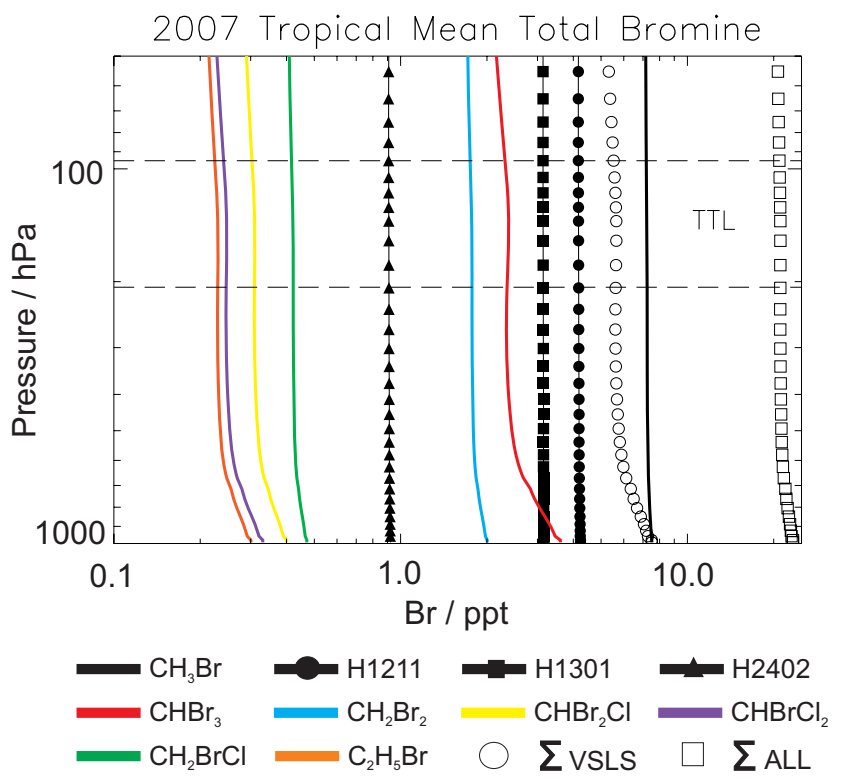

Fig. 6. Modelled tropical mean total bromine (ppt) for 2007 and from simulation $S_{\text {archived }}$. Dashed horizontal lines denote the approximate base of the TTL and the cold-point tropopause (CPT).

precipitation. This increases the likelihood of wet deposition of soluble $\mathrm{Br}_{\mathrm{y}}$ in certain regions. We would also expect variation depending on the parameterisation of cumulus convection used in the model. Here the Tiedtke (1989) scheme is used but different parameterisations that provide more (less) frequent/intense convective upwelling would likely increase (decrease) the modelled SGI. As the removal of soluble products are coupled to the convective precipitation this could also lead to a decrease (increase) in the delivery of $\mathrm{Br}_{\mathrm{y}}$ from VSLS reaching the stratosphere via the PGI route. Physical atmospheric removal of $\mathrm{Br}_{\mathrm{y}}$ in the TTL is also possible from adsorption on to ice. However, according to recent model work, this process (not considered here) represents only a small sink (Aschmann et al., 2011).

Our modelled $\mathrm{Br}_{\mathrm{y}}^{\mathrm{VSLS}}$ from $\mathrm{CHBr}_{3}$ and $\mathrm{CH}_{2} \mathrm{Br}_{2}$ alone ( $\sim 4 \mathrm{ppt})$ is slightly lower than the $5 \mathrm{ppt}$ reported by Liang et al. (2010) but larger than our previously reported $2.4 \mathrm{ppt}$ (Hossaini et al., 2010). This is due to the explicit modelling of wet deposition, resulting in a larger contribution from the PGI route in our present work. For $\mathrm{CHBr}_{3}$, we find here $0.97 \mathrm{ppt}$ of $\mathrm{Br}_{\mathrm{y}}$ reaches the tropical lower stratosphere via the PGI route. This is $\sim 3 \times$ larger than the 0.3 ppt reported in Hossaini et al. (2010).

The minor VSLS individually provide a modest amount of total bromine to the lower stratosphere. The largest contributor, $\mathrm{CH}_{2} \mathrm{BrCl}$, provides about one fifth that of $\mathrm{CHBr}_{3}$. However, their accumulated total $\left(\sim 1.2 \mathrm{ppt}\right.$ from $\left.\mathrm{S}_{\text {archived }}\right)$ is significant and is likely a lower limit due to $\mathrm{nPB}, \mathrm{iPB}$ and EDB not considered in the calculation. The contribution of all VSLS considered here and also the long-lived species to total stratospheric bromine is shown in Fig. 6 . The model $\left(S_{\text {archived }}\right)$ shows $\sim 21 \mathrm{ppt}$ of total bromine in the stratosphere. We find a total $\mathrm{Br}_{\mathrm{y}}^{\mathrm{VSLS}}$ supply of $\sim 4.9-5.2 \mathrm{ppt}$ for runs $S_{\text {diagnosed }}$ and $S_{\text {archived }}$, respectively. This range is consistent with the inferred $\mathrm{Br}_{\mathrm{y}}^{\mathrm{VSLS}}$ supply of $5.2( \pm 2.5) \mathrm{ppt}$ by Dorf et al. (2008). This study used ballon-borned DOAS (Differential Optical Absorption Spectroscopy) measurements of $\mathrm{BrO}$ in the stratosphere. Combined with modelling work the authors were able to infer the VSLS $\mathrm{Br}_{y}$ contribution (from the $\mathrm{BrO} / \mathrm{Br}_{y}$ ratio). Our $\mathrm{Br}_{\mathrm{y}}^{\mathrm{VSLS}}$ estimate of $\sim 4.9-5.2 \mathrm{ppt}$ is also in reasonable agreement with estimates based on ground-based $\mathrm{BrO}$ observations; for example, 6 (3-9) ppt (Schofield et al., 2006). However, it is significantly lower than the estimate of $8.4(6.4-10.4)$ ppt of Sioris et al. (2006) from SCIAMACHY satellite BrO profiles.

Of the VSLS with a solely anthropogenic source, we have only considered $\mathrm{C}_{2} \mathrm{H}_{5} \mathrm{Br}$ in our calculated value of $\mathrm{Br}_{\mathrm{y}}^{\mathrm{VSLS}}$. Our result may therefore represent a lower limit due to EDB, $\mathrm{nPB}$ and iPB not being included in the calculation. Montzka and Reimann et al. (2011) estimate that minor anthropogenic VSLS including $\mathrm{C}_{2} \mathrm{H}_{5} \mathrm{Br}$, EDB and nPB species contribute $<0.2 \mathrm{ppt}$ via the SGI pathway. Our model shows $\mathrm{C}_{2} \mathrm{H}_{5} \mathrm{Br}$ and EDB are sufficiently long-lived to be potentially important carriers of bromine to the stratosphere. Simulations show, regardless of the surface vmr, $\sim 70-73 \%$ and $80-85 \%$ of total surface bromine from $\mathrm{C}_{2} \mathrm{H}_{5} \mathrm{Br}$ and EDB in the tropics can reach the lower stratosphere.

We have also quantified tropospheric loss of the major long-lived SGs. Tropospheric loss of the halons in the model was found to be negligible. For $\mathrm{CH}_{3} \mathrm{Br}$ we find $\sim 0.7 \mathrm{ppt}$ of source gas is removed in the troposphere from $\mathrm{S}_{\text {diagnosed }}$; $9 \%$ of the assumed $7.5 \mathrm{ppt}$ surface boundary condition. This is consistent with the estimated $\mathrm{CH}_{3} \mathrm{Br}$ gradients of $0-15 \%$ reported by Schauffler et al. (1999). The PGI route still allows $\sim 0.33$ ppt of the resulting $\mathrm{Br}_{\mathrm{y}}$ to enter the stratosphere. Therefore, $\sim 0.4 \mathrm{ppt}$ of bromine is physically removed from the atmosphere ( $\sim 5 \%$ of the surface boundary condition). This result implies that estimates of $\mathrm{Br}_{\mathrm{y}}^{\mathrm{VSLS}}$ that ignore tropospheric gradients of $\mathrm{CH}_{3} \mathrm{Br}$ may have a low bias of $0.4 \mathrm{ppt}$ or so (though this may be compensated for by omission of minor VSLS). This result is likely sensitive to the model $\mathrm{OH}$ field and also treatment of wet deposition; both of which carry some uncertainty. For $\mathrm{OH}$, our model reads monthly averaged 24-h mean values from a previous full chemistry integration. Tropospheric variability in $\mathrm{OH}$ is large and observations are sparse. However, comparison of $\mathrm{OH}$ profiles from the 1999 NASA PEM TROPICS-B campaign with modelled profiles (not shown), show reasonable agreement. The model $\mathrm{OH}$ field in this case was found to be within the min-max variability of the available observations from the surface to $200 \mathrm{mb}$. However, we acknowledge that model $[\mathrm{OH}]$ is still a potential source of error. 


\section{Conclusions}

We have used a 3-D offline CTM and improved our previous estimate of the contribution of VSLS on the stratospheric bromine budget. We have considered 9 VSLS, methyl bromide and also four halons source gases. Modelled profiles of these gases give good agreement with tropical observations from the recent 2009 HIPPO-1 aircraft campaign. Both model and observations reiterate that a significant amount of total stratospheric bromine may arise from naturally-emitted VSLS. The observations did not detect significant levels of anthropogenic-VSLS. However, ethyl bromide $\left(\mathrm{C}_{2} \mathrm{H}_{5} \mathrm{Br}\right)$ was detected at $\sim 0.4 \mathrm{ppt}$ in the TTL. Anthropogenic VSLS likely contribute only a small amount of bromine to the present day stratosphere. However, observations of these species are limited and more data is needed to support this conclusion.

Both ethyl bromide and ethylene dibromide (EDB) are long-lived in the tropical tropopause layer and thus are potentially efficient carriers of bromine to the stratosphere. The simulated local atmospheric lifetime of these anthropogenic gases are up to $\sim 183$ and 603 days in the TTL, respectively. Therefore locally, these gases may breach the WMO working defintion of a very short-lived substance (i.e. lifetimes less than 6 months). Other anthropogenic gases considered, npropyl bromide and i-propyl bromide are shorter-lived. The maximum simulated local lifetimes in the TTL are $\sim 39$ and 49 days.

Our model shows the contribution of the VSLS $\mathrm{CHBr}_{3}$, $\mathrm{CH}_{2} \mathrm{Br}_{2}, \mathrm{CHBr}_{2} \mathrm{Cl}, \mathrm{CHBrCl}_{2}, \mathrm{CH}_{2} \mathrm{BrCl}$ and $\mathrm{C}_{2} \mathrm{H}_{5} \mathrm{Br}$ to stratospheric $\mathrm{Br}_{\mathrm{y}}$ is 4.9-5.2 ppt for the present day, consistent with balloon-borne estimates. This may represent a lower limit as three anthropogenic gases, EDB, n-propyl bromide and iso-propyl bromide are not included in the calculation. Approximately $76 \%$ of this supply comes from $\mathrm{CHBr}_{3}$ and $\mathrm{CH}_{2} \mathrm{Br}_{2}$. To date, most model work has focused on these species. Our study shows minor VSLS (e.g. $\mathrm{CHBr}_{2} \mathrm{Cl}$, $\mathrm{CH}_{2} \mathrm{BrCl}$ ) individually contribute modest amounts. However, their overall total is significant and comparable to that of one of the major VSLS (e.g. $\mathrm{CH}_{2} \mathrm{Br}_{2}$ ). Omission of these minor species in model simulations may result in an underestimate of stratospheric $\mathrm{Br}_{\mathrm{y}}$ by $\sim 1.2$ ppt. More observations of these gases, particularly in the upper TTL, are required to further constrain estimates of their contribution to stratospheric $\mathrm{Br}_{\mathrm{y}}$. Ongoing work to identify the largest geographical source regions of VSLS and to determine sea-air fluxes will ultimately lead to an improved treatment of emissions in global models.

Acknowledgements. This work was supported by the UK NERC and the EU SHIVA project (SHIVA-226224-FP7-ENV-2008-1). RH thanks NERC for a studentship. WF is part funded by NCAS. We thank S. Wofsy as head PI for HIPPO, C. Sweeney for assistance in NOAA/ESRL flask sampling during HIPPO and at RTA, and B. Hall for calibration standards. Data from the HIPPO Program was supported by NSF grants to Harvard University, University of California (San Diego), UCAR, Uni. Colorado/CIRES, Uni. Miami and by NCAR. Participation by NOAA/ESRL station data and airborne instruments, and weather forecasting, were supported in part by the NSF through its Atmospheric Chemistry Program to CIRES, NOAA/ESRL through its Atmospheric Composition and Climate Program and the Office of Oceanic and Atmospheric Research, and NASA through its Upper Atmosphere Research and Radiation Sciences Programs. EA acknowledges the contributions of R. Lueb, R. Hendershot, X. Zhu, and L. Pope to the sampling and analysis of HIPPO samples.

Edited by: M. Dameris

\section{References}

Aschmann, J., Sinnhuber, B.-M., Atlas, E. L., and Schauffler, S. M.: Modeling the transport of very short-lived substances into the tropical upper troposphere and lower stratosphere, Atmos. Chem. Phys., 9, 9237-9247, doi:10.5194/acp-9-9237-2009, 2009.

Aschmann, J., Sinnhuber, B.-M., Chipperfield, M. P., and Hossaini, R.: Impact of deep convection and dehydration on bromine loading in the upper troposphere and lower stratosphere, Atmos. Chem. Phys., 11, 2671-2687, doi:10.5194/acp-11-2671-2011, 2011.

Breider, T., Chipperfield, M. P., Richards, N. A. D., Carslaw, K. S., Mann, G. W., and Spracklen, D. V.: The impact of $\mathrm{BrO}$ on dimethylsulfide in the remote marine boundary layer, Geophys. Res. Lett., 37, L02807, doi:10.1029/2009GL040868, 2010.

Carpenter, L. J., Sturges, W. T., Penkett, S. A., Liss, P. S., Alicke, B., Hebestreit, K., and Platt, U.: Short-lived alkyl iodides and bromides at Mace Head, Ireland: links to biogenic sourcesand halogen oxide production, J. Geophys. Res.-Atmos., 104, 1679-1689, 1999.

Chipperfield, M.: New version of the TOMCAT/SLIMCAT offline chemical transport model: intercomparison of stratospheric tracer experiments, Q. J. Roy. Meteor. Soc., 132, 1179-1203, doi:10.1256/qj.05.51, 2006.

Dorf, M., Butz, A., Camy-Peyret, C., Chipperfield, M. P., Kritten, L., and Pfeilsticker, K.: Bromine in the tropical troposphere and stratosphere as derived from balloon-borne $\mathrm{BrO}$ observations, Atmos. Chem. Phys., 8, 7265-7271, doi:10.5194/acp-87265-2008, 2008.

Feng, W., Chipperfield, M. P., Dhomse, S., Monge-Sanz, B. M., Yang, X., Zhang, K., and Ramonet, M.: Evaluation of cloud convection and tracer transport in a three-dimensional chemical transport model, Atmos. Chem. Phys., 11, 5783-5803, doi:10.5194/acp-11-5783-2011, 2011.

Giannakopoulos, C., Chipperfield, M. P., Law, K. S., and Pyle, J. A.: Validation and intercomparison of wet and dry deposition schemes using $\mathrm{Pb}-210$ in a global three-dimensional off-line chemical transport model, J. Geophys. Res., 104, 23761-23784, 1999.

Hossaini, R., Chipperfield, M. P., Monge-Sanz, B. M., Richards, N. A. D., Atlas, E., and Blake, D. R.: Bromoform and dibromomethane in the tropics: a 3-D model study of chemistry and transport, Atmos. Chem. Phys., 10, 719-735, doi:10.5194/acp-10-719-2010, 2010. 
Hoyle, C. R., Marécal, V., Russo, M. R., Allen, G., Arteta, J., Chemel, C., Chipperfield, M. P., D’Amato, F., Dessens, O., Feng, W., Hamilton, J. F., Harris, N. R. P., Hosking, J. S., Lewis, A. C., Morgenstern, O., Peter, T., Pyle, J. A., Reddmann, T., Richards, N. A. D., Telford, P. J., Tian, W., Viciani, S., Volz-Thomas, A., Wild, O., Yang, X., and Zeng, G.: Representation of tropical deep convection in atmospheric models Part 2: Tracer transport, Atmos. Chem. Phys., 11, 8103-8131, doi:10.5194/acp-11-8103-2011, 2011.

Khalil, M. A. K. and Rasmussen, R. A.: The trend of $\mathrm{CBrClF}_{2}$ and other Br-containing gases at the South Pole, Antarct. J. US, 19, 206-207, 1985.

Laube, J. C., Engel, A., Bönisch, H., Möbius, T., Worton, D. R., Sturges, W. T., Grunow, K., and Schmidt, U.: Contribution of very short-lived organic substances to stratospheric chlorine and bromine in the tropics - a case study, Atmos. Chem. Phys., 8, 7325-7334, doi:10.5194/acp-8-7325-2008, 2008.

Law, K. S. and Sturges, W. T.: Halogenated very short-lived substances, in: Scientific Assessment of Ozone Depletion: 2006, Global Ozone Research and Monitoring Project, Report No. 50, Chapt. 2, edited by: World Meteorological Organization, Geneva, 2007.

Liang, Q., Stolarski, R. S., Kawa, S. R., Nielsen, J. E., Douglass, A. R., Rodriguez, J. M., Blake, D. R., Atlas, E. L., and Ott, L. E.: Finding the missing stratospheric $\mathrm{Br}_{\mathrm{y}}$ : a global modeling study of $\mathrm{CHBr}_{3}$ and $\mathrm{CH}_{2} \mathrm{Br}_{2}$, Atmos. Chem. Phys., 10, 2269-2286, doi:10.5194/acp-10-2269-2010, 2010.

Low, J. C., Wang, N. Y., Williams, J., and Cicerone, R. J.: Measurements of ambient atmospheric $\mathrm{C}_{2} \mathrm{H}_{5} \mathrm{Cl}$ and other ethyl and methyl halides at coastal California sites and over the Pacific Ocean, J. Geophys. Res., 108, 4608, doi:10.1029/2003JD003620, 2003.

Montzka, S. A., Butler, J. H., and Hall, B. D.: A decline in tropospheric organic bromine, Geophys. Res. Lett., 30, 1826, 2003.

Montzka, S. A. and Reimann, S.: Ozone-depleting substances (ODSs) and related chemicals, in: Scientific Assessment of Ozone Depletion: 2010, Global Ozone Research and Monitoring Project, Report No. 52, Chapt. 1, edited by: World Meteorological Organization, Geneva, Switzerland, 2011.

Pratt, G. C., Palmer, K., Wu, C. Y., Oliaei, F., Hollerbach, C., and Fenske, M. J.: An assessment of air toxics in Minnesota, Environ. Health Perspect., 108, 815-825, 2000.

Sander, S. P., Friedl, R. R., Golden, D. M., Kurylo, M. J., Moortgat, G. K., Keller-Rudek, H., Wine, P. H., Ravishankara, A. R., Kolb, C. E., Molina, M. J., Finlayson-Pitts, B. J., Huie, R. E., and Orkin, V. L.: Chemical Kinetics and Photochemical Data for Use in Atmospheric Studies, Evaluation Number 15, JPL Publication 06-2, Jet Propulsion Laboratory, Pasadena, CA, USA, 2006.
Schauffler, S. M., Atlas, E. L., Blake, D. R., Flocke, F., Lueb, R. A., Lee-Taylor, J. M., Stroud, V., and Travnicek, W.: Distributions of brominated organic compounds in the troposphere and lower stratosphere, J. Geophys. Res., 104, 21513-21535, 1999.

Schofield, R., Johnston, P. V., Thomas, A., Kreher, K., Connor, B. J., Wood, S., Shooter, D., Chipperfield, M. P., Richter, A., von Glasow, R., and Rodgers, C. D.: Tropospheric and stratospheric BrO columns over Arrival Heights, Antarctica, 2002, J. Geophys. Res., 111, D22310, doi:10.1029/2005JD007022, 2006.

Schofield, R., Fueglistaler, S., Wohltmann, I., and Rex, M.: Sensitivity of stratospheric $\mathrm{Br}_{\mathrm{y}}$ to uncertainties in very short lived substance emissions and atmospheric transport, Atmos. Chem. Phys., 11, 1379-1392, doi:10.5194/acp-11-1379-2011, 2011.

Sinnhuber, B. M., Arlander, D. W., Bovensmann, H., Burrows, J. P., Chipperfield, M. P., Enell, C. F., Friess, U., Hendrick, F., Johnston, P. V., Jones, R. L., Kreher, K., Mohamed-Tahrin, N., Muller, R., Pfeilsticker, K., Platt, U., Pommereau, J. P., Pundt, I., Richter, A., South, A. M., Tornkvist, K. K., Van Roozendael, M. Wagner, T., and Wittrock, F.: Comparison of measurements and model calculations of stratospheric bromine monoxide, J. Geophys. Res., 107, 4398, doi:10.1029/2001JD000940, 2002.

Sioris, C. E., Kovalenko, L. J., McLinden, C. A., Salawitch, R. J., Roozendael, M. V., Goutail, F., Dorf, M., Pfeilsticker, K., Chance, K., von Savigny, C., Liu, X., Kurosu, T. P., Pommereau, J. P., Boesch, H., and Frerick, J.: Latitudinal and vertical distribution of bromine monoxide in the lower stratosphere from Scanning Imaging Absorption Spectrometer for Atmospheric Chartography limb scattering measurements, J. Geophys. Res., 111, D14301, doi:10.1029/2005JD006479, 2006

Stockwell, D. Z. and Chipperfield, M. P.: A tropospheric chemical transport model: development and validation of the model transport schemes, Q. J. Roy. Meteorol. Soc., 125, 1747-1783, 1998.

Sturges, W. T., Oram, D. E., Carpenter, L. J., Penkett, S. A., and Engel, A.: Bromoform as a source of stratospheric bromine, Geophys. Res. Lett., 27, 2081-2084, 2000.

Tiedtke, M. A.: A comprehensive mass flux scheme for cumulus parameterisation in large-scale model, Mon. Weather Rev., 117, 1779-1800, 1989.

Warwick, N. J., Pyle, J. A., Carver, G. D., Yang, X., Savage, N. H., O'Connor, F. M., and Cox, R. A.: Global modeling of biogenic bromocarbons, J. Geophys. Res., 111, D24305, doi:10.1029/2006jd007264, 2006.

Wofsy, S. C.: the HIPPO science team and cooperating modellers and satellite teams: HIAPER Pole-to-Pole Observations (HIPPO): fine-grained, global-scale measurements of climatically important atmospheric gases and aerosols, Phil. Trans. R. Soc. A, 369, 2073-2086, doi:10.1098/rsta.2010.0313, 2011. 